\title{
Critical Risks Factor (CRF) for Construction Delay Mitigation in Provincially/Municipally-Owned Corporation (BUMD)
}

\author{
Nandang Sutisna ${ }^{1}$, Isdaryanto Iskandar ${ }^{2}$, Hery Suliantoro $^{3}$ \\ \{nandang.sutisna@ideaprolog.com ${ }^{1}$, isdaryanto@atmajaya.ac.id ${ }^{2}$, herysuliantoro@lecturer.undip.ac.id ${ }^{3}$ \} \\ Faculty of Engineering, Atma Jaya Catholic University of Indonesia ${ }^{1}$, \\ Study Program of Information System, STIKOM CKI², \\ Departement of Industrial Engineering, Diponegoro University ${ }^{3}$
}

\begin{abstract}
The performance of construction procurement in BUMD (Badan Usaha Milik Daerah/The Provincially/Municipally-Owned Corporation) affects the company's performance, especially when the resulting construction is related to producing goods/services that are a source of income. On the other hand, delays in construction procurement waste human resources, time, and budget. Therefore, mitigation of construction procurement delays becomes essential to avoid potential losses. The study aims to conduct a Critical Risks Factor (CRF) analysis on BUMD construction procurement to mitigate potential delays. This study was conducted with a literature study to determine 27 risk factors that cause delays in construction procurement, divided into five categories and 15 mitigation strategies. The survey was conducted on 70 BUMD with four types of respondents: Board of Directors (Direksi), Procurement Users (Pengguna Barang/Jasa), Commitment Making Officers (PPK/Pejabat Pembuat Komitmen), and Procurement Committee/Officials (Panitia/Tim Pengadaan) with total valid data are 104 respondents. The results showed that delays occurred due to weak preliminary study, contract management, weak coordination, and sectoral ego. The solution is to increase procurement planning, contract management, and better relationships among procurement actors.
\end{abstract}

Keyword: Critical Risks Factor; Construction Procurement; Delays Mitigation; Provincially/Municipally Owned Corporation (BUMD)

\section{Introduction}

Every BUMD needs to carry out construction procurement to provide buildings for their use or for interests related to goods/services that are a source of income. The construction of the Water Work System (SPAM/Sistem Penyediaan Air Minum) on Municipal Waterwork (PDAM/Perusahaan Daerah Air Minum) has a significant impact because clean water services result from SPAM construction. Likewise, for Municipal Market Corporation (Perusahaan Daerah/PD Pasar), the market building becomes the primary source of income. Therefore, the 
implementation of construction procurement must be done promptly. Delays in the completion of the work will significantly impact the company's business [1].

The procurement budget in BUMD has a large proportion of value to total revenue. For certain BUMD whose income relies on construction, such as PDAM on the construction of waterwork construction system (SPAM) or PD Pasar on its market buildings, the proportion of procurement budget can be even more significant. Improper procurement management can potentially cause large losses, significantly when the procurement that affects the production of goods/services, in addition to material losses, can also impact non-material losses. Material losses can be loss of business momentum, waste of budget, and disruption of goods/services, while non-material losses can be from declining trust and even customer abandonment.

Several studies discuss delays in construction procurement both in government, BUMD, and the private sector. Each study has different characteristics and is influenced by various specific factors. The study aims to discuss mitigating delays in construction procurement caused by internal factors from budget owners. The internal factors are human resources and regulation or procurement procedure, planning, Tender, Pre-Contract, and Contract. The study did not address delay factors caused by contractors or other factors.

The determinants of delay and mitigation strategies will be determined through literature studies and then compiled by dividing the question into five categories with 27 factors that cause delays in construction procurement: human resources and regulation, planning stages, tender stage, pre-contracts stage, and contracts stage. Furthermore, a survey was conducted on the procurement of goods/services in BUMD, which was divided into the categories of Directors, Procurement Users, Commitment Making Officers, and Procurement Committees/Officials to assess what factors must be protected to be the cause of construction procurement delays in their organizations.

\section{Literature Review}

\subsection{Cause of Delays in Human Resource and Regulatory Factors}

Delays in construction procurement can be caused by factors related to human resources and regulation. These factors relate to the duties and authorities in carrying out the project and the regulations. Factors related to low coordination, poor quality of communication, the length of approval, and procurement personnel do not have competence. For factors that cause delays in construction procurement-related regulations or procedures, including complex and convoluted regulation, procurement processes without implementing procurement strategies, duties and personnel authorities that are biased or unclear, and procurement is still done manually, not using e-procurement ([2]; [3]; [4]; [5]; and [6]).

\subsection{Cause of Delays in Planning Stage Factors}

Planning failure can also cause delays in construction procurement. It can have a prolonged impact because it will affect the next stage. Failure to determine and implement procurement planning becomes the beginning of the project's failure. Delays in construction procurement can also be caused by several matters related to planning, such as failure in planning, scheduling, and design, failure in budget setting, failure in technical requirements of tenders, problems related to regulations and permits, preliminary feasibility studies, and problems with budget availability ([2], [7], [5], dan [8]). 


\subsection{Cause of Delays in Tender Stage Factors}

Construction procurement delays caused by problems in the Tender process are another factor that causes delays in construction procurement. Some of the factors that cause delays in the Tender process include unfair price offers, delays in the tender process, unclear or confusing tender processes, failed tenders, planning periods to tenders too long, and incomplete bidding documents ([9], [5], [10], [11], dan [12]).

\subsection{Cause of Delays in Contract Stage Factors}

Delays in construction procurement can be caused by factors related to the implementation of contracts, including tender to contracts too long, weak contract management, contract changes or addendum, late payments, weak control supervision, and contract disputes ([13], [5], [14], [8], dan [15]).

\subsection{Delays Mitigation Strategy}

Mitigation strategies to anticipate delays in construction procurement can be done by improvement of procurement regulation or SOPs, the use of e-Procurement and the alignment of Tender provisions or requirements and increased corruption prevention (Karimi et al., 2020); increased commitment to leadership and management, and training staff to improve the competence [16]; improving the quality of planning and implementation of contract risk management (Asmitha, 2019); improving the quality of budget planning and setting sufficient time allocations (Jongo et al., 2019); project budget readiness [18]; and improved quality of supervision and payment (Banobi \& Jung, 2019). Further details of mitigation strategies for construction procurement delays are shown in Table 2.

\section{Methodology}

The study was conducted by establishing the factors that caused construction procurement delays from a literature review. Five factors cause delays in construction procurement, consisting of 27 causative factors and 15 mitigation strategies. Then from the data compiled questionnaires that will be used as a survey filling language to four types of respondents, namely Directors, Procurement Users, Commitment Making Officers, and Procurement Committees / Procurement Officials. Furthermore, data analysis is done using statistical applications.

\subsection{Questionnaire Design}

Questionnaires are organized into three sections consisting of: (1) respondent information; (2) causes of construction procurement delays; and (3) mitigation strategies to anticipate delays. The causes of delay are five: human resources development and regulation, group B: planning stage, group C: tender stage, group D: pre-contract stage, and group E: contract stage. Each group can be seen in Table 1 below.

The factors causing delays in construction procurement are then used for questionnaire surveys to pre-determined respondents. Each respondent was asked to assess each of the factors that caused the delay in construction procurement. The assessment is given with the provision of each respondent answering these factors as the cause of construction procurement delays with 
values 1 (strongly disagree), 2 (disagree), 3 (doubtful), 4 (agree), and 5 (strongly agree).

Table 1. Delays Risk Factors

\begin{tabular}{|c|c|c|c|}
\hline Category & Code & Delays Factor & References \\
\hline Human Resources & A1 & Weak coordination and sectoral ego & {$[2][3][4][5][6]$} \\
\hline \multirow{7}{*}{ and Regulations } & A2 & Weak communication & \\
\hline & A3 & Slow approval & \\
\hline & A4 & Incompetent personnel & \\
\hline & A5 & Complicated Procurement Processes & \\
\hline & A6 & No Procurement Strategy & \\
\hline & A7 & The responsibilities are unclear & \\
\hline & A8 & Manual/Non-eProc Procurement & \\
\hline \multirow[t]{6}{*}{ Planning Stage } & B1 & Weak technical planning & {$[2][7][5][8]$} \\
\hline & B2 & Budget planning issues & \\
\hline & B3 & Tender Terms & \\
\hline & B4 & Regulations and permits & \\
\hline & B5 & Weak preliminary study & \\
\hline & B6 & Financial problems & \\
\hline \multirow[t]{6}{*}{ Tender } & $\mathrm{C} 1$ & Low price offer & {$[9][5][10][11][12]$} \\
\hline & $\mathrm{C} 2$ & Late Tender & \\
\hline & $\mathrm{C} 3$ & Unclear Tender criteria & \\
\hline & $\mathrm{C} 4$ & Tender Failed & \\
\hline & $\mathrm{C} 5$ & Planning to Tender too long & \\
\hline & C6 & Contractor offers are not serious & \\
\hline Pre-Contract & D1 & Tender to Contract too long & {$[19]$} \\
\hline \multirow[t]{6}{*}{ Contract } & E1 & Contract period too short & {$[13][5][14][8][15]$} \\
\hline & E2 & Weak contract management & \\
\hline & E3 & $\mathrm{COO}$ or addendum & \\
\hline & E4 & Late payment & \\
\hline & E5 & Weak contract supervision & \\
\hline & E6 & Contract disputes & \\
\hline
\end{tabular}

The next step is to establish mitigation strategies to anticipate delays in construction procurement obtained from literature studies. The mitigation strategy relates to human resources development and regulation, improvements in planning, tenders, pre-contract, and contract stages. The mitigation strategy questionnaire will be given to respondents by assessing the impact of the mitigation strategy against the decrease in construction procurement delays. Values 1 (strongly disagree), 2 (disagree), 3 (doubtful), 4 (agree) and 5 (strongly agree). The respondents were asked to have five mitigation strategies needed by their organizations to mitigate construction procurement delays. A list of mitigation strategies can be seen in Table 2 .

Table 2. Delays Mitigation Strategy

\begin{tabular}{llc}
\hline No & \multicolumn{1}{c}{ Mitigation Strategy } & References \\
\hline M1 & Improvement of procurement regulation & {$[6]$} \\
M2 & Use of e-Procurement & {$[6]$} \\
M3 & Leadership and Management Commitment & {$[16]$} \\
M4 & Competency training for all & {$[16]$} \\
M5 & Prevention of corruption & {$[6]$} \\
M6 & Improving the quality of planning & {$[7]$} \\
M7 & Improving the quality of budget planning & {$[17]$} \\
M8 & Sufficient time allocation & {$[17]$} \\
M9 & Project budget readiness & {$[18]$} \\
\hline
\end{tabular}




\begin{tabular}{clc}
\hline No & \multicolumn{1}{c}{ Mitigation Strategy } & References \\
\hline M10 & Implementation of procurement strategy & {$[18]$} \\
M11 & Alignment of Tender provisions & {$[6]$} \\
M12 & Application of contract risk analysis & {$[7]$} \\
M13 & Improved quality of contract supervision & {$[2]$} \\
M14 & Timely payment & {$[2]$} \\
M15 & Comprehensive contract documents & {$[18]$} \\
\hline
\end{tabular}

\subsection{Survey}

The survey was conducted to construction procurement actors spread across 70 BUMD with the number of respondents as many as 104 respondents consisting of:

1. The Board of Directors is an official who has the duty and authority to establish planning and order the finance department to make payments to the contractor when the work is declared completed;

2. Procurement Users are work units that are usually held by managers, section heads, or other equivalent positions that have the duty and authority to determine the needs of goods /services;

3. Commitment Making Officer is an official who has the duty and authority to make procurement preparations and carry out contracts; and

4. Procurement Committee/Official is a team of personnel who have the task and authority to carry out tender or direct construction procurement.

The profile of respondents is structural position, procurement position, education level, length of work, use of e-Procurement, the number of construction procurement packages, and the total value of construction procurement. Complete respondent profiles are presented in Table 3.

Table 3. Respondents Profile

\begin{tabular}{lrr}
\hline \multicolumn{3}{c}{ Structural Position } \\
\hline Board of Director & 9 & $9 \%$ \\
Manager & 39 & $37 \%$ \\
Assistant Manager & 23 & $22 \%$ \\
Staff/Non-structural & 33 & $32 \%$ \\
\hline \multicolumn{2}{c}{ Procurement Position } \\
\hline Board of Director & 5 & $5 \%$ \\
Procurement User & 5 & $5 \%$ \\
CMO & 19 & $18 \%$ \\
Procurement Committee/Official & 75 & $72 \%$ \\
\hline \multicolumn{3}{c}{ Educational Level } \\
\hline High School & 5 & $5 \%$ \\
Bachelor/Diploma Degree & 75 & $72 \%$ \\
Master/Ph.D Degree & 24 & $23 \%$ \\
\hline \multicolumn{3}{c}{ Procurement Experiences } \\
\hline Under 5 years & 35 & $34 \%$ \\
5 - 10 years & 44 & $42 \%$ \\
More than 10 years & 25 & $24 \%$ \\
\hline \multicolumn{2}{c}{ eProcurement Users } \\
\hline Yes & 67 \\
No & $64 \%$ \\
\hline \multicolumn{2}{c}{ Construction Budget Yearly } \\
\hline
\end{tabular}




\begin{tabular}{lrr}
\hline Less than Rp2,5 Milyar & 63 & $61 \%$ \\
Rp2,5 to 10 Milyar & 27 & $26 \%$ \\
More than Rp10 Milyar & 14 & $13 \%$ \\
\hline \multicolumn{4}{l}{ Construction Procurement Package Yearly } \\
\hline Less than 10 package & 33 & $32 \%$ \\
10 to 50 package & 41 & $39 \%$ \\
More than 10 package & 30 & $29 \%$ \\
\hline
\end{tabular}

The questionnaire was conducted online using the google document application and submitted randomly and serially to BUMD procurement actors. Data processing is carried out by calculating RII (relative importance index) to determine the most dominant factors that cause delays in construction procurement in BUMD. RII values are used to determine the relative importance of various causes of delay. RII is calculated for each factor that causes delays in BUMD construction procurement with the following equations[20]:

$\mathrm{RII}_{\mathrm{i}}=\frac{\mathrm{n} 1+2 \mathrm{n} 2+3 \mathrm{n} 3+4 \mathrm{n} 4+5 \mathrm{n} 5}{5(\mathrm{n} 1+\mathrm{n} 2+\mathrm{n} 3+\mathrm{n} 4+\mathrm{n} 5)}$

Information:

$\mathrm{RII}_{\mathrm{i}} \quad=$ Relative Importance Index for factor $\mathrm{i}$;

$\mathrm{n} 1, \mathrm{n} 2, \mathrm{n} 3, \mathrm{n} 4, \mathrm{n} 5=$ number of respondents representing the number 1 (strong disagree), 2 (disagree), 3 (doubtful), 4 (agree), and 5 (strong agree).

To survey mitigation strategies for construction procurement delays are carried out by way of respondents determining the five strategies most needed for their companies to minimize the risk of delays in construction procurement.

\section{Analysis and Result}

The data obtained is processed using descriptive statistics, then calculated the dominant factors that cause delays in construction procurement in BUMD. Reliability test using Alpha Cronbach with a result of 0.949 means that all survey results data can be trusted. Determination of the dominant factors that cause delays in construction procurement is based on the calculation of RII with the following results:

Table 4. RII the key factors that cause delays

\begin{tabular}{clcccc}
\hline No & \multicolumn{1}{c}{ Delays Factors } & Code & Total Value & Respondents & RII \\
\hline 1 & Weak preliminary study & B5 & 378 & 104 & 0,73 \\
2 & Weak contract management & E2 & 378 & 104 & 0,73 \\
3 & Weak coordination \& sectoral ego & A1 & 373 & 104 & 0,72 \\
4 & Weak technical planning & B1 & 369 & 104 & 0,71 \\
5 & Weak contract supervision & E5 & 369 & 104 & 0,71 \\
6 & Weak communication & A2 & 366 & 104 & 0,70 \\
7 & Slow approval & A3 & 353 & 104 & 0,68 \\
8 & Incompetent personnel & A4 & 345 & 104 & 0,66 \\
9 & Budget planning issues & B2 & 343 & 104 & 0,66 \\
10 & Planning to Tender too long & C5 & 340 & 104 & 0,65 \\
11 & Financial problems & B6 & 335 & 104 & 0,64 \\
12 & COO or addendum & E3 & 333 & 104 & 0,64 \\
13 & Late payment & E4 & 332 & 104 & 0,64 \\
\hline
\end{tabular}




\begin{tabular}{clcccc}
\hline No & \multicolumn{1}{c}{ Delays Factors } & Code & Total Value & Respondents & RII \\
\hline 14 & No Procurement Strategy & A6 & 329 & 104 & 0,63 \\
15 & The responsibilities are unclear & A7 & 325 & 104 & 0,63 \\
16 & Contractor offers are not serious & C6 & 322 & 104 & 0,62 \\
17 & Complicated Processes & A5 & 321 & 104 & 0,62 \\
18 & Manual/Non-eProc Procurement & A8 & 320 & 104 & 0,62 \\
19 & Unclear Tender criteria & C3 & 307 & 104 & 0,59 \\
20 & Tender Failed & C4 & 307 & 104 & 0,59 \\
21 & Tender Terms & B3 & 304 & 104 & 0,58 \\
22 & Low price offer & C1 & 304 & 104 & 0,58 \\
\hline
\end{tabular}

Based on the RII value above, it is seen that the risk factor for delays in construction procurement in BUMD is caused by the weak preliminary study with a value of 0.73 . This condition shows that BUMD construction procurement is not done with adequate planning and preparation. Poor planning and preparation on BUMD construction procurement because the determination of reactional and rushed needs ignores long-term planning. The next cause is weak contract management with the same value as the weak preliminary study of 0.73 . The cause of weak contract management can occur because no official is specifically responsible for managing the Contract. Structural or double office officials often hold Commitment Making Officials (PPK), so they cannot carry out their roles optimally.

The next cause is related to weak coordination and sectoral ego with a value of 0.72 , weak technical planning with a value of 0.71 , and weak contract planning with a value of 0.71 . These delay risk factors are also associated with planning, contract management, and weak construction procurement organizations in BUMD. To determine mitigation strategies minimize construction procurement delays are carried out by ranking based on strategies that are widely chosen by respondents, with the following results:

Table 5. The most chosen mitigation strategies

\begin{tabular}{clcc}
\hline No & \multicolumn{1}{c}{ Mitigation Strategy } & Code & Respondents Choice \\
\hline 1 & Improvement of procurement regulation & M1 & $16,22 \%$ \\
2 & Use of e-Procurement & M3 & $14,16 \%$ \\
3 & Leadership and Management Commitment & M2 & $12,64 \%$ \\
4 & Competency training for all & M4 & $11,70 \%$ \\
5 & Prevention of corruption & M5 & $9,82 \%$ \\
6 & Improving the quality of planning & M6 & $6,98 \%$ \\
7 & Improving the quality of budget planning & M11 & $3,78 \%$ \\
8 & Sufficient time allocation & M9 & $3,02 \%$ \\
9 & Project budget readiness & M10 & $2,84 \%$ \\
10 & Implementation of procurement strategy & M12 & $2,84 \%$ \\
11 & Alignment of Tender provisions & M13 & $2,84 \%$ \\
12 & Application of contract risk analysis & M15 & $2,84 \%$ \\
13 & Improved quality of contract supervision & M7 & $2,64 \%$ \\
14 & Timely payment & M8 & $2,46 \%$ \\
15 & Comprehensive contract documents & M14 & $1,88 \%$ \\
\hline
\end{tabular}

Based on the survey results to respondents, the results obtained procurement regulation as a much-needed mitigation strategy with a value of $16.22 \%$. Furthermore, the consecutive use of e-Procurement $14,16 \%$, leadership commitment and management $12,64 \%$, competency training for all $11,70 \%$, and corruption prevention $9,82 \%$. These results show that the main issues in efforts to prevent delays in BUMD construction procurement are regulation and e-procurement users. 


\section{Conclusions and Recommendation}

This study was conducted to determine what risk factors cause delays in the procurement of BUMD construction. Furthermore, this study also found out what procurement actors need mitigation strategies to minimize risk factors that cause delays in construction procurement. Based on the results obtained from the survey of BUMD construction procurement respondents, the most dominant risk factors to be the cause of construction procurement delays are the weak preliminary study and technical planning, weak management and supervision of contracts, and coordination sectoral ego problems. This result shows that the main problem is the procurement actors' planning, Contract, and personnel barriers.

Mitigation strategies widely chosen by respondents include increasing procurement regulations, and the use of e-Procurement is a much-needed mitigation strategy. This result shows that BUMD construction procurement regulation is considered not optimal so that improvement is needed. Similarly, e-Procurement is two of the mitigation strategies most needed to reduce the risk of delays in BUMD construction procurement.

Based on the above meeting, there are problems in planning, contracting, and human resource arrangements in the procurement of BUMD construction. To anticipate this, it requires improved procurement regulation and the use of e-Procurement. In addition, there are also weaknesses in terms of human resource competence and the division of tasks that have not been good among BUMD procurement actors. So that the improvement of BUMD construction procurement regulations is also included in it related to human resources and BUMD construction procurement organizations.

This descriptive study explains the initial allegations of factors that cause delays in the procurement construction on BUMD. However, it is unknown exactly how much effect it has on BUMD procurement construction delays, so further studies are needed.

\section{References}

[1] M. Z. Mhlanga, E. Munapo, and N. Mavetera, "Investigating causes of delays and cost escalation in project execution during turnarounds," Invest. Manag. Financ. Innov., vol. 13, no. 2, pp. 334-348, 2016, doi: 10.21511/imfi.13(2-2).2016.08.

[2] E. T. Banobi and W. Jung, "Causes and mitigation strategies of delay in power construction projects: Gaps between owners and contractors in successful and unsuccessful projects," Sustain., vol. 11, no. 21, 2019.

[3] G. Muneeswaran, P. Manoharan, P. O. Awoyera, and A. Adesina, "A statistical approach to assess the schedule delays and risks in Indian construction industry," Int. J. Constr. Manag., vol. 20, no. 5, pp. 450-461, 2020, doi: 10.1080/15623599.2018.1484991.

[4] J. Bisbey, S. H. H. Nourzad, C.-Y. Chu, and M. Ouhadi, "Enhancing the efficiency of infrastructure projects to improve access to finance," J. Infrastructure, Policy Dev., vol. 4, no. 1, p. 27, 2020, doi: 10.24294/jipd.v4i1.1175.

[5] N. D. Long, S. Ogunlana, T. Quang, and K. C. Lam, "Large construction projects in developing countries: A case study from Vietnam," Int. J. Proj. Manag., vol. 22, no. 7, pp. 553-561, 2004, doi: 10.1016/j.ijproman.2004.03.004.

[6] S. Karimi, Z. Zhakfar, and M. I. Sarwary, "Study of Excessive Bureaucracy in Construction Projects - Causes of Low Level of Competition and Lengthy Tendering 
Process: A Case Study of Afghanistan," Int. J. Eng. Adv. Technol., vol. 10, no. 1, pp. 66-73, 2020, doi: 10.35940/ijeat.a1707.1010120.

[7] P. Asmitha, "Time Delay and Cost Overrun in Construction Projects," IRE J., vol. 3, no. 5, pp. 368-375, 2019, doi: 10.1016/j.proeng.2016.11.632.

[8] B. Al Khatib, Y. S. Poh, and A. El-Shafie, "Delay factors in reconstruction projects: A case study of Mataf Expansion Project," Sustain., vol. 10, no. 12, 2018, doi: $10.3390 /$ su10124772.

[9] M. R. Abdullah, I. Abdul Rahman, and A. A. Abdul Azis, "Causes of Delay in MARA Management Procurement Construction Projects," J. Surv. Constr. Prop., vol. 1, no. 1, pp. 1-16, 2010, doi: 10.22452/jscp.vol1no1.6.

[10] R. C. Marques and S. Berg, "Risks, Contracts, and Private-Sector Participation in Infrastructure," J. Constr. Eng. Manag., vol. 137, no. 11, pp. 925-932, 2011, doi: 10.1061/(asce)co.1943-7862.0000347.

[11] G. Rachman, M. mun Sarma, and D. Rachmina, "Strategies for Improvement of Government Budget Absorption of Bogor City," J. Sos. Sci., vol. 1, no. 5, pp. 195-203, 2020, doi: 10.46799/jsss.v1i5.69.

[12] R. M. Choudhry, H. F. Gabriel, M. K. Khan, and S. Azhar, "Causes of discrepancies between design and construction in the Pakistan construction industry," J. Constr. Dev. Ctries., vol. 22, no. 2, pp. 1-18, 2017, doi: 10.21315/jcdc2017.22.2.1.

[13] S. M. T. Naqash and S. Singla, "Significant factors affecting delays in construction projects in northern region of India and their relation with cost," Int. J. Sci. Technol. Res., vol. 8, no. 11, pp. 3053-3057, 2019.

[14] R. F. Aziz and A. A. Abdel-Hakam, "Exploring delay causes of road construction projects in Egypt," Alexandria Eng. J., vol. 55, no. 2, pp. 1515-1539, 2016, doi: 10.1016/j.aej.2016.03.006.

[15] A. Aljohani, "Construction Projects Cost Overrun: What Does the Literature Tell Us?," Int. J. Innov. Manag. Technol., vol. 8, no. 2, pp. 137-143, 2017, doi: 10.18178/ijimt.2017.8.2.717.

[16] A. H. Memon, I. Abdul Rahman, and A. A. Abdul Azis, "Time and Cost Performance in Construction Projects in Southern and Central Regions of Peninsular Malaysia," Int. J. Adv. Appl. Sci., vol. 1, no. 1, 2012, doi: 10.11591/ijaas.v1i1.537.

[17] J. S. Jongo, D. N. G. A. K. Tesha, R. Kasonga, J. J. Teyanga, and K. S. Lyimo, "Mitigation Measures in Dealing with Delays and Cost Overrun in Public Building Projects in Dar-Es-Salaam, Tanzania," Int. J. Constr. Eng. Manag., vol. 8, no. 3, pp. 8196, 2019, doi: 10.5923/j.ijcem.20190803.01.

[18] M. Abedi, M. F. Mohamad, and M. S. Fathi, "Major Mitigation Measures for Delays in Construction Projects," in Iranian Students Scientific Conference, 2011, pp. 1-7.

[19] J. A. Alsuliman, "Causes of delay in Saudi public construction projects," Alexandria Eng. J., vol. 58, no. 2, pp. 801-808, 2019, doi: 10.1016/j.aej.2019.07.002.

[20] I. E. Lianto and B. Anondho, "Analisis Besaran Koefisien Ketidakpastian Environmental Uncertainty (EU) yang Berpengaruh Pada Perhitungan Buffer Pada Critical Chain Project Management (CCPM) di Jakarta,” JMTS J. Mitra Tek. Sipil, vol. 1, no. 2, p. 143, 2018, doi: 10.24912/jmts.v1i2.2671. 